\title{
Economic Effects of the 2003 Partial Integration Proposal in the United States
}

\author{
R. GLENN HUBBARD * \\ Columbia University; National Bureau of Economic Research, New York, NY 10027
}

rgh1@columbia.edu

\begin{abstract}
On January 7, 2003, President George W. Bush proposed a significant change in capital income taxation in the United States. In the context of a "jobs and growth" package, the President proposed to reduce substantially the double taxation of corporate-source income by eliminating investor-level taxes on dividends paid from earnings on which corporate tax had been paid. In addition, the President's proposal would have reduced the tax on retained earnings by allowing a basis adjustment for accumulated previously taxed retained earnings. Taken together, these proposals would have moved the U.S. income tax much closer to an integrated tax system along the lines outlined by the Treasury Department in President George H.W. Bush's administration a decade earlier.

Putting together the impacts of the President's proposal on economic activity through greater capital accumulation and improved calculation, I estimate that the proposal, if it had been enacted in its original form, would yield a permanent increase of 0.48 percent in the U.S. economy's potential output. This estimated gain does not include any gains made possible by improved corporate financial policy.
\end{abstract}

Keywords: integration, dividend taxes, capitail gains taxes

JEL Code: H2, H6

\section{Introduction}

On January 7, 2003, President George W. Bush proposed a significant change in capital income taxation in the United States. In the context of a "jobs and growth" package, the President proposed to reduce substantially the double taxation of corporate-source income by eliminating investor-level taxes on dividends paid from earnings on which corporate tax had been paid. ${ }^{1}$ In addition, the President's proposal would have reduced the tax on retained earnings by allowing a basis adjustment for accumulated previously taxed retained earnings. Taken together, these proposals would have moved the U.S. income tax much closer to an integrated tax system along the lines outlined by the Treasury Department in President George H.W. Bush's administration a decade earlier.

The tax law change approved by the Congress and signed by President Bush in the spring of 2003 departed from the initial proposal, by providing temporary tax rate cuts on dividends and capital gains; the dividend rate cut was not conditional on prior payment of corporate tax. In what follows, I consider the economic effects of the President's initial proposals, as 
they are closer to a "textbook" integration experiment than the actual legislation. The paper is organized as follows. Section 2 revisits economic arguments for corporate tax integration. Section 3 describes the integration prototypes recommended by the Treasury Department (1992) that served as a model for President Bush's proposal. In Section 4, I offer estimates of the economic effects of the President's proposal. Section 5 concludes.

\section{Arguments for Corporate Tax Integration ${ }^{2}$}

\subsection{Background}

Current U.S. income tax law treats corporations and their investors as separate entities. Under this so-called "classical" system of corporate taxation, two levels of tax are levied on earnings from investments in corporate equity. First, income earned by corporations is taxed at the corporate level. Second, when the corporation distributes dividends to shareholders, the income is taxed at the shareholder level as ordinary income. Undistributed earnings, which increase share values, are also double-taxed, because they are taxed at capital gains rates when shares are sold.

In contrast, investors who conduct business activity in noncorporate form, such as a sole proprietorship or partnership (or in corporate form through an S corporation), are taxed once on their earnings at their individual tax rate. Corporate earnings distributed as interest to suppliers of debt capital are generally taxed to U.S. taxpayers as ordinary income. However, interest paid is generally deductible by the corporation, and thus not subject to tax at the corporate level.

"Integration" of the corporate and individual income taxes refers to any plan in which corporate income is taxed only once, rather than taxed both when earned and when distributed to shareholders as dividends. Integration has many variants. In January 1992, the U.S. Treasury Department released a study of corporate tax integration, Integration of the Individual and Corporate Tax Systems (hereafter, "the Treasury Report"); the American Law Institute published a set of proposals the same year. The Treasury Report documents the economic distortions caused by the current two-tier tax system and the need to change the way in which the United States taxes corporations and their shareholders, and presents the issues involved with alternative approaches.

Despite their differences, the methods of integration studied in the Treasury Report and the American Law Institute Report reflect a common goal: To the extent practicable, fundamental economic considerations, not the tax structure, should guide investment, organizational, and financial decisions. Although the Tax Reform Act of 1986 reduced the effect of taxation on many business decisions, that reform did not directly address distortions in business organizational and financing decisions under current law. Thus integration can be viewed as the next logical step in tax reform.

\subsection{The Corporate Tax and Economic Distortions}

The classical corporate tax system distorts economic and financial decisions, including whether to: (1) invest in noncorporate rather than corporate form; (2) finance investments 
with debt rather than equity; and (3) retain rather than distribute earnings. In addition to the corporate and individual tax considerations, each of these decisions has nontax attributes, as well.

2.2.1. Organizational Form. Traditional arguments for integrating corporate and individual income taxes emphasize distortions of business organizational form (Harberger, 1962, 1966). By taxing corporate equity income twice, the classical corporate tax system discourages equity-financed investment by corporate organizations. Also, it means that the corporate sector must earn a higher pre-tax rate of profit to prevent capital from flowing to the noncorporate sector. The tax distorts the allocation of resources by discouraging the use of the corporate form even when incorporation would provide nontax benefits-such as limited liability for the owners, centralized management, free transferability of interests, and continuity. Since Harberger's seminal research, more sophisticated models have been constructed to determine the costs of the economic distortions caused by the corporate income tax (see studies reviewed in the Treasury Report; Shoven and Whalley, 1984). For example, Harberger's original model delineated only noncorporate and corporate sectors; some researchers developed models with more sectoral detail.

More recently, models emphasizing shifts in the relative importance of corporate and noncorporate producers within an industry have suggested greater distortions under the corporate tax than estimated by earlier approaches (Gravelle and Kotlikoff, 1989). The additional cost arises because corporate and noncorporate producers within an industry possess differential advantages. Corporations may be better able to exploit scale economies, while noncorporate organizations may be better able to encourage entrepreneurial skill. Distorting the choice between these corporate forms thus means diminishing the use of scale economies, as well.

The tax bias against corporate equity investment must be placed in the context of other tax considerations. For example, when the source of corporate equity investment is retained earnings, rather than new share issues, then the funds for investment are taxed at the corporate level and as capital gains to investors, reducing substantially the scope of double taxation. At various times and in certain industries, the combination of the corporate tax rate and the effective tax rate on capital gains has been greater than, equal to, and less than the individual income tax rate on business income. In this way, differences among tax rates may reduce, eliminate, or even reverse the bias against investment by corporations. In other cases, sophisticated tax planning or "tax shelters" can reduce or eliminate double taxation (and even a portion of single taxation). An additional mitigating factor is the use of debt financing; to the extent that corporations finance investments through debt, the relative tax advantage for noncorporate businesses is reduced.

2.2.2. Corporate Capital Structure Corporations have three alternatives for financing new investments: issuing new equity, using retained earnings, or issuing debt. The classical corporate tax system discriminates against equity financing of new corporate investment; because corporate profits are taxed twice, the cost of equity capital generally exceeds the cost of debt capital. Projects funded with new equity or retained earnings therefore require a higher pre-tax rate of return than projects financed with debt. The lower effective tax rate 
for debt-financed than for equity-financed corporate investment encourages the use of debt finance by corporations, holding nontax factors constant.

Indeed, if debt issuance involved no nontax considerations, corporate borrowing would be an efficient type of "self help" integration, because interest payments are deductible. Stiglitz (1973), for example, demonstrates that in the absence of nontax benefits and costs of debt finance, the corporate tax does not distort marginal investment decisions (since firms will use debt finance at the margin to take advantage of the deductibility of interest payments). The burden of the corporate tax would be borne by the initial equity. However, because (as I argue below) alternative corporate financing arrangements can have important nontax benefits and costs, the tax system should avoid prejudicing financial decisions.

Leverage may well offer nontax benefits. Those analysts who are most sanguine about high levels of corporate debt and debt-service burdens typically maintain that the "discipline" of debt is desirable because it empowers lenders with an indirect means to monitor the activities of managers (Jensen, 1986). Lenders brandishing the threat of pushing a firm into bankruptcy may well have more power to monitor the performance of a firm's managers than fragmented shareholder ownership.

But in practice, increased debt financing may be an ineffective way to improve managerial incentives when most of the variation is common across business enterprises-as with industry-wide or business cycle fluctuations (Gertler and Hubbard, 1993). Thus even when there are incentive benefits associated with debt finance, the most efficient financial arrangements will involve both debt and equity, with equity serving as a cushion against economy-wide fluctuations in profitability.

Higher debt levels can increase nontax costs of debt, including costs associated with financial distress. Even when corporations avoid formal bankruptcy proceedings, they can incur costs of entering into covenants that restrict operating flexibility when they cannot meet their interest obligations. The costs can include extra demands on executives' time, supply disruptions, declines in customers' confidence, and significant legal fees. Corporations must therefore evaluate the tax and nontax benefits of additional debt relative to these costs.

2.2.3. Corporate Dividend Distributions The current system of corporate income taxation may also distort a corporation's choice between distributing or retaining earnings and, if amounts are distributed, whether they are paid in the form of a nondividend distribution, such as a share repurchase. Distributing earnings through dividends will be taxed relatively highly versus distributing earnings through capital gains generated by reinvested earnings or share repurchases.

Financial economists have offered two explanations to explain why corporate dividends are paid despite the tax bias against dividend distributions (Treasury Report, 1992; Poterba and Summers, 1985). The first-known as the "traditional view"-argues that dividends offer nontax benefits to shareholders that offset their apparent tax disadvantage. For example, analogous to the earlier discussion of nontax benefits of debt finance, high dividend payouts may decrease managerial discretion over internal funds. Alternatively, dividends may provide signals to investors about a firm's prospects or relative financial strength, although the need to maintain dividend payments as a signal will constrain the use of retained earnings as a corporation's source of financing for new investments. Under the 
traditional view, marginal investment is financed by new share issues. In addition, firms set dividend payments so that, for the last dollar of dividends paid, the incremental nontax benefit of dividends equals their incremental tax cost. Thus the amount of dividends paid out is expected to decrease as the tax burden on dividends relative to capital gains increases. Based on the empirical evidence that attempts to distinguish between the traditional view and the alternative "tax capitalization view" (described below), this traditional approach is the one taken by the 1992 Treasury Report. Zodrow (1991) summarizes this research.

The second explanation, or "tax capitalization view," assumes that dividends offer no nontax benefits to shareholders relative to retained earnings. An additional assumption in this view is that corporations have no alternative to dividends (like share repurchases) for distributing funds to shareholders at the margin. As a result, investor-level taxes on dividends reduce the value of the firm as they are capitalized in share value, but would generally affect neither corporate dividend nor investment decisions. Under the assumptions of the tax capitalization view, corporate tax integration would not encourage corporations to increase dividend payouts, but would confer benefit to holders of existing equity (for supporting empirical evidence, see Harris, Hubbard and Kemsley, 2001). ${ }^{3}$

The distortions of business organizational and financial decisions under the current classical corporate tax system suggest that corporate tax integration might be desirable. But deciding upon a particular method of integrating the corporate and individual tax systems requires coming to grips with a variety of complex issues among competing prototypes.

\section{Prototypes for Corporate Integration}

\subsection{Dividend Relief}

Most proposals for integration-including the proposal by President Bush—have focused on eliminating the double taxation of those earnings that are distributed; in short, dividend relief. ${ }^{4}$ A number of options are possible. In an "imputation credit" system, tax is collected at the corporate level, but shareholders receive a credit to apply against investor-level taxes. In a "dividend deduction" system, corporations could deduct dividend payments just as they do interest payments in calculating taxable income. Or in a "dividend exclusion" system, shareholders would not be taxed on dividend income.

The imputation credit prototype might work this way: Corporations would determine their income for tax purposes as they do now and would pay a corporate-level tax. Shareholders would include in their income the "grossed-up" amount of the dividend-that is, both the dividend and the associated tax paid at the corporate level. They could apply toward individual tax payments a credit equal to the amount of corporate tax that would be associated with the gross dividends. This system is similar to the taxation of wages and salaries for employees, in which an employee includes gross wages in taxable income and receives a credit equal to the amount of tax withheld.

A dividend deduction system would treat dividends and interest payments symmetrically at the corporate level. Moreover, a proposal to deduct dividends paid - at least the portion attributable to income on which corporate tax has been paid—would be significantly more 
expensive than other forms of dividend relief, and would make it difficult to collect one layer of tax on corporate-source income as many shares are held by tax-exempt institutions including pension funds and foreign investors.

The Treasury Report recommended a dividend exclusion prototype for dividend relief as the most straightforward means of implementing the general policy recommendations within the context of reforms requiring the least change from current law. Under this prototype, corporations would pay the corporate income tax, computing taxable income in the same way as under current law. However, dividends paid out of fully taxed corporate income would not be taxed again at the investor level.

Though not usually considered in traditional analyses of corporate tax integration, the existence of capital-market imperfections affects the choice of an integration prototype. Under the simplest neoclassical model of the firm with perfect capital markets, the decision of whether to grant dividend relief at the firm level or the investor level is determined by whether one believes that corporate income should be taxed once at the corporate tax rate (as in the Treasury Report) or once at progressive shareholder tax rates, (as in the American Law Institute Report), and by administrative considerations. However, transactions costs of issuing securities and costs arising from asymmetric information can make external financing more expensive than internal financing (for example, Greenwald, Stiglitz and Weiss, 1984; Fazzari, Hubbard and Petersen, 1988). As a result, it may be inappropriate to allow firms and shareholders to benefit from integration only to the extent that internally generated funds are paid out as dividends.

Because retained (already fully taxed) earnings would bear a greater tax burden than distributed earnings under dividend relief models, corporations would have an incentive to distribute rather than retain earnings. The dividend exclusion prototype could be easily extended to avoid the double taxation of retained earnings. The Report outlines a "dividend reinvestment plan," which would allow a corporation to declare deemed dividends, treating the dividend as reinvested in the corporation. Hence shareholders would be treated as if they had received an excludable dividend, and the stock's basis would be increased, avoiding a subsequent capital gains tax on retained earnings.

\subsection{More Neutral Treatment of Debt and Equity}

Integration prototypes reduce the differences in the tax treatment of debt and equity finance. Differences need not be eliminated, however. For example, the Treasury Report's imputation credit and dividend exclusion prototypes would retain the current level of corporate taxes on equity income received by tax-exempt and foreign investors. As long as interest payments remain deductible, the tax system would still create a bias toward debt investments by such investors. This problem can be addressed at either the investor level or the firm level, as was the case for dividend relief.

The Treasury Report developed in detail a broad extension of the dividend exclusion prototype to interest expense and income. Treasury's prototype-the Comprehensive Business Income Tax (CBIT) - would apply to all businesses, noncorporate and corporate, with the exception of very small firms. CBIT would represent fundamental shifts in the taxation of capital income, and the Report presents it as a long-term option. 
Under the CBIT prototype, neither deductions for payments to debt-holders nor to equityholders would be permitted, and a tax would be collected at the entity level (at a rate equal to the highest marginal individual tax rate). However, both interest and equity distributions generally would be excludable from income by investors. If all business income were taxed at the entity level and investors excluded all interest and dividend income, taxing capital gains would create a significant disparity between distributed and retained earnings. An exemption for capital gains (and disallowance of losses) on equity and debt of CBIT entities would be consistent with the general exemption of dividends and interest from the investor-level tax under CBIT.

CBIT would eliminate tax distortions in organizational form, capital structure, and dividend policy more completely than any of the other prototypes (other than full "partnership form" integration). Indeed, the only difference between CBIT and the Flat Tax variant of a consumption tax would be the maintenance of depreciation allowances under the former and expensing of capital goods purchased under the latter (see the discussion in Gentry and Hubbard, 1997).

\section{Quantifying the Benefits of Integration}

The direction of the tax biases under pre-2003 tax law is clear. The size of the resulting inefficiency will be determined by how much households and firms respond to these tax considerations. Formal economic analysis is difficult because behavioral responses in one market affect other markets. For example, when the corporate tax drives capital from the corporate sector, rates of return in the noncorporate sector are affected.

\subsection{Gains Estimated in the 1992 Treasury Report}

The economic benefits from corporate tax integration appear to be significant. The gains result from improved allocation of real resources, reductions in the likelihood of firm's experiencing financial distress, and the shift toward allowing corporations to make capital structure and dividend decisions based on nontax benefits and costs. Estimated increases in economic well-being from integration are in many cases as large as gains suggested for the reforms in the Tax Reform Act of 1986 (see Fullerton, Henderson and Mackie, 1987; Gravelle, 1989 assuming the traditional view.)

The Treasury Report offers estimates of the effects of various integration prototypes. Depending on the prototype, model, and financing assumption, the increase in the share of capital used in the corporate sector ranges from two to eight percentage points. In addition, the integration prototypes generally encourage corporations to use less debt. Estimated debt-to-asset ratios decrease by from one to seven percentage points. The integration prototypes encourage corporations to increase the portion of earnings distributed as dividends. Depending on the model, financing assumption, and prototype, dividend payout ratios rise modestly by between two to six percentage points.

By shifting resources into the corporate sector, reducing corporate borrowing, and encouraging dividends, the prototypes generate changes in economic well-being. Each 
prototype improves economic welfare, with the estimated improvement ranging from an amount equivalent to 0.07 percent of annual consumption (that is, total consumer spending on goods and services) to an amount equivalent to 0.73 percent of consumption, a substantial portion of the tax revenue currently generated from corporate capital income. The estimated gains are largest for the CBIT prototype, because it generally eliminates the tax bias against corporate equity issues and dividend distributions. The Treasury Department's estimated gains assumed that taxes on capital income would be increased, as necessary, to compensate for any revenue lost as a result of integration.

\subsection{Estimated Gains from the President's 2003 Proposal}

There are at least four channels through which the corporate tax integration proposed by President Bush in 2003 could affect the long-run productive capacity of the economy:

1. The plan would reduce the cost of capital by ending the double tax on corporate income, increasing the capital stock and output.

2. The plan would improve the overall productivity of the economy by reducing tax distortions between corporate and noncorporate investment.

3. The plan would reduce financial structure distortions arising from the differential taxation of debt and equity.

4. The plan would eliminate the tax bias against dividend payouts. Firms with few profitable investment opportunities would have no tax motivation not to return funds to shareholders, who could then reinvest funds in other, more productive ventures.

In what follows, I analyze gains in potential output from the first two channels.

4.2.1. Increased Capital Stock The President's proposal contained a permanent tax cut on capital income from dividends and capital gains. Calculating the effect requires several steps. The first, calculating the reduction in the user cost of capital to corporations by ending the double tax on corporate income, requires assumptions about financial policy. The greatest reductions in the cost of capital occur for new share issues, on which much of the investment's return is effectively subject to taxation at shareholders' ordinary tax rates under current law. Investments financed through retained earnings benefit by a smaller amount because these investments are subject to taxation at the lower effective capital gains tax rates under current law. Because interest payments are deductible, debt-financed investments are not presently subject to double taxation and do not receive a benefit under the President's proposal. Under assumptions that financing is 65 percent equity (evenly divided between returned earnings and new share issues and 35 percent debt and that shareholders providing additional equity to corporations are subject to the average marginal tax rate, the Treasury Department (2003) estimates that the President's original proposal would reduce the user cost of capital by 3.25 percent.

Second, this reduction in the user cost is overstated to the extent that the plan is financed in part by an increase in government debt. ${ }^{5}$ At the same time, the reduction in the tax-based 
distortions to investment would bring about an increase in the demand for saving. Both the reduction in national saving and the increase in the national demand for saving would put upward pressure on interest rates. In an open economy such as the United States, a slight increase in domestic interest rates is sufficient to create incentives to increase the net flow of foreign saving into the United States. This increase in interest rates is further muted to the extent the higher after-tax return induces an increase in domestic saving rates.

Council of Economic Advisers (2003) estimates that the decline in national saving would be expected to raise interest rates by about 1.5 basis points for every $\$ 100$ billion in additional net borrowing, given the standard relationship between output and capital in the economy. Based on the likely responses of domestic saving and domestic investment to the President's proposal, a reasonable assumption is that interest rates would rise by about 10 basis points, or one-tenth of one percentage point. With this offset, using the Treasury Department's estimate of the user cost decline from integration reduces the fall in the user cost to 2.38 percent.

Third, in equilibrium, firms equate the user cost of capital to the additional output that a unit of capital generates. The quantitative link between the marginal product of capital and the size of the capital stock is derived by the relationship between the economy's productive inputs (capital, labor, and technology) and output (GDP). Using a Cobb-Douglas production function with a capital share of 0.3 implies an increase in the capital stock of 1.43 percent for each one percent reduction in the user cost of capital.

This third effect reflects two considerations. Some empirical analysis is consistent with the proposition that, holding output constant, a firm will raise its desired capital stock by one percent in response to a one percent decrease in the cost of capital (see Cummins, Hassett and Hubbard, 1996). Because the President's proposal does not reduce the taxation of non-capital inputs, output will expand under the proposal. Because output expands, the increase in desired capital due to a lower user cost is larger than one-for-one.

Fourth, the estimated effect for the aggregate capital stock must be recalibrated to the corporate capital stock. Most of the nation's capital is owned outside the corporate sector, for example as noncorporate businesses or as owner-occupied housing. In 2001, about 31 percent of the capital stock was held by corporations.

Fifth, one can now calculate the effect of higher corporate capital on long-run outcome. Because the share of capital income in total output is about 30 percent, output would be expected to rise by about 30 percent of the increase in capital, or 0.31 percent (= $2.38 \times 1.43 \times 0.31 \times 0.30$ ).

Finally, while eliminating the dividend tax has no direct tax consequences for businesses outside of the corporate sector, increases in interest rates resulting from the plan would reduce the desired capital stocks of these firms. Using the same assumptions leading to an increase in interest rates of ten basis points and given a share of non-residential, noncorporate capital in the total capital stock of about nine percent would result in a 0.06 percent decline in output due to a lower capital stock in the corporate sector.

Taken together, these effects suggest a permanent total percentage change in the long-run level of output due to capital accumulation of 0.25 percent. 
4.2.2. Improved Capital Allocation The President's integration proposal would reduce the tax burden on corporate capital relative to noncorporate capital, allowing capital to be used more efficiently and augmenting the amount of output that the economy can produce with a given capital stock.

The efficiency gains for the dividend exclusion prototype estimated in the 1992 Treasury Report offer a guide here. The report's estimate of an efficiency gain of 0.39 percent of annual consumption ${ }^{6}$ implies an output gain of about 0.27 percent per year. This gain overstates the effect of the President's proposal for two reasons. First, the President's proposal would allow tax-free dividend payouts only for corporate income on which corporate tax has been paid. Second, while the Treasury Report assumed that new share issues were the marginal source of financing, following the calculation in section B1 above, the estimate I used above assumes that one-third of new capital raised comes from new equity issues. Finally, the President's proposal would allow investors to increase the basis of their shares when returned earnings come from corporate income on which corporate tax has been paid.

The Treasury Department's (2003) analysis estimates that on balance, only 59 percent of the allocation efficiency gains from the 1992 proposal would be obtained with the 2003 proposal. Hence productivity gains from improved allocation can be estimated to be $0.27 \times$ $0.59=0.16$ percent per year. Transforming this productivity gain to a gain in output, taking into account induced investment, as in section B1 above, implies a percentage change in the long-run level of output of 0.23 percent per year because of more efficient capital allocation.

Putting together the effects of greater capital accumulation and improved capital allocation yield a permanent increase of 0.48 percent in the economy's potential output. As noted above, this estimated gain does not include any gains made possible by improved corporate financial policy.

\section{Conclusion}

Integrating the corporate and individual income tax systems is not a new topic. The Treasury Department's 1992 Report stimulated new thinking by economists and policymakers about the desirability of reducing the double taxation of corporate income in the United States. President George W. Bush's integration proposal and the ongoing discussion of the hybrid reform enacted by the Congress suggest that the topic is unlikely to fade soon.

Further advancing the integration debate requires three steps, each of which in turn requires interaction among economists, policymakers, and businesspeople. First, additional research is needed on the factors affecting the organizational and financial decisions of firms, including international dimensions. Second, discussion should focus on basic policy judgments-for example, about the treatment of tax preferences and tax-exempt shareholders. Finally, with a better understanding of the economic benefits of integration and basic policy judgments, individual models for integration can be debated.

President Bush's corporate tax integration proposal also has important implications for international taxation, in particular the tax treatment of U.S. multinationals. For example, the dividend exclusion model proposed by the President could be consistent with an exemption system in which U.S. multinationals would not pay tax on dividends received from a controlled foreign corporation. Hence the debate over extensions of the President's 
proposal is likely to bring about discussions of reform of the tax treatment of multinational companies' overseas income as well (see, e.g., Avi-Yonah, 2005).

\section{Notes}

1. The President's tax proposal also included acceleration of certain credits and reductions in marginal tax rates enacted in the Economic Growth and Tax Reduction Act of 2001.

2. Parts of the discussion in this section draw on Hubbard (1993).

3. In the context of President Bush's 2003 proposal, the tax capitalization view would suggest that stock prices would rise in response to integration, strengthening household and corporate balance-sheet positions.

4. An alternative approach would treat the corporation as a conduit, taxing all corporate earnings, irrespective of whether they are distributed, once at the shareholder level. For a discussion of full integration, see McLure (1979).

5. Most economic analysis of integration assumes a revenue-neutral tax reform. President Bush's integration proposal was a tax reduction contained within a package of proposals aimed at boosting near-term economic growth.

6. See U.S. Treasury Department (1992), page 134, Table 13.8, Panel B.

\section{References}

American Law Institute, Federal Income Tax Project. (1992). Reporter's Study Draft, Integration of the Individual and Corporate Income Taxes. Philadelphia. Memo written by Professor Alvin C. Warren of Harvard Law School.

Avi-Yonah, R. S. (2005). "The Pitfalls of International Integration: A Comment on the Bush Proposal and its Aftermath," International Tax and Public Finance, 12(1), 87-95.

Council of Economic Advisers. (2003). Economic Report of the President. Washington, D.C., U.S. Government Printing Office.

Cummins, J. G., K. A. Hassett and R. G. Hubbard. (1996). "Tax Reforms and Investment: A Cross-country Comparison," Journal of Public Economics 62, 237-273.

Fazzari, S., R. G. Hubbard and B. C. Petersen. (1988). "Financing Constraints and Corporate Investment," Brookings Papers on Economic Activity 1, 141-195.

Fullerton, D., Y. K. Henderson and J. Mackie. (1987). "Investment Allocation and Growth Under the Tax Reform Act of 1986.” In Compendium of Tax Research, 1987. Washington, D.C.: U.S. G.P.O.

Gentry, W. M. and R. G. Hubbard. (1997). "How Different Are Income and Consumption Taxes?" American Economic Review 87(2), 138-142.

Gertler, M. and R. G. Hubbard. (1993). "Corporate Financial Policy, Taxation, and Macroeconomic Risk," RAND Journal of Economics Summer 24(3), 286-303.

Gravelle, J. G. (1989). "Differential Taxation of Capital Income: Another Look at the 1986 Tax Reform Act," National Tax Journal 47, 441-463.

Gravelle, J. G. and L. Kotlikoff. (1989). “The Incidence and Efficiency Costs of Corporate Taxation When Corporate and Noncorporate Firms Produce the Same Good," Journal of Political Economy 97(4), 749-780.

Greenwald, B., J. E. Stiglitz and A. Weiss. (1984). "Information Imperfections in the Capital Market and Macroeconomic Fluctuations," American Economic Review 74, 194-199.

Harberger, A. C. (1962). "The Incidence of the Corporation Income Tax," Journal of Political Economy 70(3), $215-240$.

Harberger, A. C. (1966). "Efficiency Effects of Taxes on Income from Capital.” In M. Krzyzaniak (ed.), Effects of the Corporation Income Tax. Detroit: Wayne State University Press, pp. 107-117.

Harris, T., R. G. Hubbard and D. Kemsley. (2001). "Are Dividend Taxes and Imputation Credits Capitalized in Share Values?," Journal of Public Economics 79, 569-596.

Hubbard, R. G. (1993). “Corporate Tax Integration: A View From the Treasury Department,” Journal of Economic Perspectives 7(1), 115-132. 
Jensen, M. C. (1986). “Agency Costs of Free Cash Flow, Corporate Finance, and Takeovers," American Economic Review 76(2), 323-329.

McLure, C. E., Jr. (1979). Must Corporate Income Be Taxed Twice? Washington, D.C.: The Brookings Institution.

Poterba, J. M. and L. H. Summers. (1985). "The Economic Effects of Dividend Taxes." In E. Altman and M. Subrahmanyam (eds.), Recent Advances in Corporate Finance. Homewood: Richard D. Irwin, pp. 227284

Shoven, J. B. and J. Whalley. (1984). "Applied General Equilibrium Models of Taxation and International Trade: Introduction and Survey," Journal of Economic Literature 22(3), 1007-1051.

Stiglitz, J. E. (1973). "Taxation, Corporate Financial Policy, and the Cost of Capital," Journal of Public Economics 2, 1-34.

U.S. Department of the Treasury. (1992). Integration of the Individual and Corporate Tax Systems: Taxing Business Income Once. Washington, D.C.: U.S. G.P.O.

U.S. Department of the Treasury. (2003). “A Dynamic Analysis of the President's Jobs and Growth Plan,” Mimeograph.

Zodrow, G. R. (1991). “On The Traditional and New Views of Dividend Taxation,” National Tax Journal 44(4), 497-509. 